\title{
AN APPROACH TO THE INTEGRATED SOLUTION OF THE PROBLEM OF STORM AND SNOW-MELT RUN-OFF TREATMENT IN URBAN AREAS OF UKRAINE
}

\author{
Oleksandr I. Spirin \\ Andriy V. Ishchenko \\ Daria S. Okhrimenko \\ National Academy of Municipal Economy, Kharkiv, Ukraine
}

\begin{abstract}
Collecting and treatment of storm and snow-melt run-off from urban areas and industrial agglomerates have been being a topical issue. Despite some climatic variations the problems are still the same: stormwater discharge is not under control, shifts in river hydrology, chemistry and biology, river pollution etc. In order to solve these problems one should enable integrated and multidisciplinary approaches taking into account environmental and ecological technologies along with architectural and land planning solutions, and demands concerning sustainable development of urban areas. To meet the requirements of these approaches and satisfy these demands it is necessary to reach minimal pollutant loading and ensure river hydrology, chemistry and biotic components much closer to natural regime. Taking this in mind it is suggested to apply specially developed systems of collecting ponds and constructed wetlands in floodplains and ox-bow lakes of urban rivers as well as intermittent watercourses like gullies and ravines. The mentioned measures will permit to strengthen structural (axial) and environmental roles of rivers in urban areas. Within urban areas these territories can and must be used for recreation, then as green bridges among developed sites providing the following important environmental functions like efficient natural purification, bio-passages (eco-corridors) in ecological network, and habitats for local flora and fauna. It is assumed that all said above could be a decisive step towards some changes in existing approaches and prevalent principles in land planning, land use, urban development and understanding the role of rivers in contemporary urban and industrial areas, more ecological compatibility taking into account more holistic landscape vision with a glance to greater sustainability.
\end{abstract}

\section{KEYWORDS}

Stormwater; Snow-melt run-off; Urban areas; Industrial agglomerates; Rivers; Ecological technologies; Floodplains; Land planning.

https://doi.org/10.15626/Eco-Tech.2010.034 


\section{INTRODUCTION}

The development of urban and industrial agglomerates results in sufficient changes in landscapes and, respectively, sufficient transformations in watersheds of continental waterbodies. It provokes forming huge quantities of polluted surface runoff having negative impact on water quality in rivers and lakes. It is well-known that urban and industrial builtups are main polluters for rivers and lakes.

With the aim to prevent deterioration of waters, damaging water ecosystems and important ecotones, contamination of groundwaters, and stimulate decrease in conflicts in water use and promote sustainable development of urban territories it is necessary to find an integrated solution for surface runoff treatment with wide systems application of ecotechnologies coupled with the introduction of landscape planning and architectural measures.

\section{CURRENT SITUATION: POLLUTION AND EXISTING SOLUTIONS}

At present various approaches to land planning of watersheds and riparian zones in Ukrainian cities and towns and application of numerical hydraulic engineering solutions (see Table 1). 
Table 1 Current practice in land planning and hydraulic engineering on urban areas and their environmental consequences in Ukraine

\begin{tabular}{|c|c|c|}
\hline $\begin{array}{l}\text { Landplanning and } \\
\text { hydroengineering } \\
\text { patterns }\end{array}$ & Aims & $\begin{array}{l}\text { Environmental consequences and } \\
\text { problems }\end{array}$ \\
\hline $\begin{array}{l}\text { 1. River breakthrough } \\
\text { 2. River culverting } \\
\text { 3. Embankment and } \\
\text { river bank lining }\end{array}$ & $\begin{array}{l}\text { Increase in areas suitable for urban } \\
\text { development. } \\
\text { River bank stabilisation. } \\
\text { Flood protection. }\end{array}$ & $\begin{array}{l}\text { Deteriorations in natural water } \\
\text { cycle. Groundwater level raise. } \\
\text { Increase in flow velocity in rivers. } \\
\text { Decrease in biodiversity. } \\
\text { Decline in selfpurification. }\end{array}$ \\
\hline $\begin{array}{l}\text { 4. River regulation via } \\
\text { damming }\end{array}$ & $\begin{array}{l}\text { High water smoothing. } \\
\text { Higher water level maintenance } \\
\text { during low water. }\end{array}$ & $\begin{array}{l}\text { Increased sedimentation. } \\
\text { Water blooms and self-pollution. } \\
\text { Groundwater level raise. }\end{array}$ \\
\hline $\begin{array}{l}\text { 5. Bank filling-up. } \\
\text { 6. Site development up } \\
\text { to water edge }\end{array}$ & $\begin{array}{l}\text { Increase in areas suitable for } \\
\text { building and urban infrastructure } \\
\text { development. }\end{array}$ & $\begin{array}{l}\text { Deterioration in natural water } \\
\text { cycle. } \\
\text { Groundwater level raise. }\end{array}$ \\
\hline $\begin{array}{l}\text { 7. Deforestation of } \\
\text { floodplains }\end{array}$ & Clearing before building & $\begin{array}{l}\text { Soil and rock erosion. } \\
\text { Increase in surface flow velocity. } \\
\text { Failure in selfpurification of } \\
\text { surface runoff and groundwater } \\
\text { flow. Derangements in organic } \\
\text { and inorganic matter exchange } \\
\text { between terrestrial and aquatic } \\
\text { ecosystems. }\end{array}$ \\
\hline $\begin{array}{l}\text { 8. Waste dumping and } \\
\text { unpurified waste water } \\
\text { disposal }\end{array}$ & $\begin{array}{l}\text { Illegal activities reflecting, from } \\
\text { one side, unsatisfactory } \\
\text { organisation of waste collecting } \\
\text { and utilisation and, from other - } \\
\text { inadequate level of environmental } \\
\text { consciousness in local communities } \\
\text { and lack of control from or direct } \\
\text { connivance of administrative } \\
\text { bodies. }\end{array}$ & $\begin{array}{l}\text { Direct pollution. } \\
\text { Decrease in biodiversity. }\end{array}$ \\
\hline
\end{tabular}

As one can see from Table 1, land planning and hydraulic engineering solutions applied serve only to increase areas suitable for building and urban infrastructure development and in this 
way they deteriorate natural water cycle, favour water pollution and negatively affect river self-purification and landscape mosaic structure on watersheds and decrease biodiversity and reflect approaches which are characteristic for extensive growth of cities and intensive industrial development of late XIX - first half of XX centuries which do not conform with the aims and tasks of sustainable development.

The problems defined in Table 1 are to a greater or lesser extent exposed in cities and towns of Ukraine. And this situation is not accidental. For instance, in the last edition of annual national environmental report [1] the problem of natural water pollution from urban and industrial territories has not been defined at all; in the General City Planning Scheme of Kharkiv [2] a chapter dedicated to sustainable development is absent. Unfortunately this deplorable list can be continued. This gives evidence concerning low attention to this problem from the side of environmental control and administrative bodies.

Thus, in Kharkiv storm and snow-melt waters are discharged from 140 spillways and outlets into rivers. Absence of treatment facilities favours to deterioration of water quality in rivers and is one of the main causes of their pollution. From year to year indices of water quality such as concentrations of oil, $\mathrm{O}_{2}, \mathrm{Fe}$, some bivalent metals, phenols and organic matter (as $\mathrm{BOD}_{5}$ ), as observed between 1991 and 2009, change mainly from bad to worse $[2,3]$.

\section{TOWARD SUSTAINABILITY IN CITY-RIVER INTERACTIONS}

It is useful to consider the suggested approach from the point of view of hierarchical complexity of problems relating to their structural levels (see Table 2).

As shown on the presented matrix in the "city-river" interactions every level of complexity complies with its own level of problems, their solutions, their technologies and measures to apply.

From the point of view of sustainable development an emphasis in urban development should be based on environmental convergence, i.e. urban development should not be opposed to natural landscapes but organically interlace with one another and reciprocally adapt to one another, e.g., housing should not be saturated but should be divided by green breaks and corridors forming specific networks there natural processes dominate over artificial ones.

The most important ecological corridors are river floodplains, esp. riparian zones, including ravine and gully network of river banks.

On our opinion floodplains and ravine and gully network within the borders of city or town should be saved by all means, redesigned and reorganised taking into account redistribution and increase of mechanical and chemical load on it, i.e., taking into account future increase in its buffer environmental capacity in relation to including new components and external change forces in the "city-floodplain" system. 
Table 2 Hierarchy of Problems of Urban and Industrial Agglomerates [4]

\begin{tabular}{|c|c|c|c|c|c|c|c|c|c|}
\hline \multirow[b]{2}{*}{$\begin{array}{c}\text { Hierarc } \\
\text { hy of } \\
\text { Natural } \\
\text { Systems }\end{array}$} & \multirow[b]{2}{*}{$\begin{array}{c}\text { Stratification } \\
\text { of Natural } \\
\text { Systems }\end{array}$} & \multirow[b]{2}{*}{$\begin{array}{c}\text { Stratificati } \\
\text { on of } \\
\text { Economic } \\
\text { Systems }\end{array}$} & \multirow[b]{2}{*}{$\begin{array}{c}\text { Hierarchy } \\
\text { of } \\
\text { Financial } \\
\text { Activity }\end{array}$} & \multirow[b]{2}{*}{$\begin{array}{c}\text { Hierarchy of } \\
\text { Educational } \\
\text { Structures }\end{array}$} & \multirow[b]{2}{*}{$\begin{array}{c}\text { Scienc } \\
e\end{array}$} & \multirow[b]{2}{*}{$\begin{array}{c}\text { Structural } \\
\text { and } \\
\text { Functiona } \\
\quad l \\
\text { Organizati } \\
\text { on of } \\
\text { Settlement } \\
\text { s }\end{array}$} & \multicolumn{3}{|c|}{ Hierarchy of Nature Protection Activity } \\
\hline & & & & & & & $\begin{array}{c}\text { Political and } \\
\text { Technologic } \\
\text { al Aspects }\end{array}$ & $\begin{array}{c}\text { Social } \\
\text { Aspects }\end{array}$ & $\begin{array}{c}\text { Freshwater } \\
\text { Resources } \\
\text { Management }\end{array}$ \\
\hline $\begin{array}{c}\text { Biosphe } \\
\text { re }\end{array}$ & $\begin{array}{l}\text { Lithosphere } \\
\text { Atmosphere } \\
\text { Hydrosphere }\end{array}$ & $\begin{array}{l}\text { World } \\
\text { Economy }\end{array}$ & Prospects & $\begin{array}{l}\text { Integration } \\
\text { into the World } \\
\text { Economic } \\
\text { System }\end{array}$ & $\begin{array}{l}\text { World } \\
\text { prioriti } \\
\text { es }\end{array}$ & Oecumena & $\begin{array}{c}\text { Global } \\
\text { Protection } \\
\text { (Protection } \\
\text { of Biosphere) }\end{array}$ & $\begin{array}{l}\text { Integration } \\
\text { of Ukrainian } \\
\text { NGOs in the } \\
\text { World Green } \\
\text { Movement }\end{array}$ & $\begin{array}{c}\text { Global } \\
\text { Programmes } \\
\text { and Action } \\
\text { Plans. } \\
\text { Global } \\
\text { Strategies. }\end{array}$ \\
\hline $\begin{array}{c}\text { II. } \\
\text { Biogeog } \\
\text { raphical } \\
\text { Region }\end{array}$ & $\begin{array}{c}\text { Euro- } \\
\text { Siberian, } \\
\text { Ancient } \\
\text { Mediterranea } \\
\mathrm{n}\end{array}$ & $\begin{array}{l}\text { A Division } \\
\text { in World } \\
\text { Economy }\end{array}$ & Policy & $\begin{array}{l}\text { Integration } \\
\text { into the } \\
\text { European } \\
\text { System }\end{array}$ & $\begin{array}{l}\text { Europe } \\
\text { an } \\
\text { traditio } \\
\text { ns }\end{array}$ & $\begin{array}{l}\text { European } \\
\text { Structures }\end{array}$ & $\begin{array}{c}\text { Intergovernm } \\
\text { ental } \\
\text { Projects, } \\
\text { Agreements, } \\
\text { Programmes, } \\
\text { Action Plans }\end{array}$ & $\begin{array}{c}\text { Forming } \\
\text { Public } \\
\text { Opinion, } \\
\text { Influence on } \\
\text { State Policy }\end{array}$ & $\begin{array}{c}\text { Transboundar } \\
\text { y Rivers and } \\
\text { Basins. } \\
\text { Intergovernm } \\
\text { ental Projects } \\
\text { and } \\
\text { Agreements }\end{array}$ \\
\hline
\end{tabular}




\begin{tabular}{|c|c|c|c|c|c|c|c|c|c|}
\hline $\begin{array}{c}\text { III. } \\
\text { Natural } \\
\text { and } \\
\text { Climatic } \\
\text { Zone }\end{array}$ & $\begin{array}{c}\text { Temperate } \\
\text { Zone }\end{array}$ & $\begin{array}{c}\text { Branch } \\
\text { Complexes }\end{array}$ & $\begin{array}{l}\text { Financing } \\
\text { on macro- } \\
\text { level } \\
\text { (junction } \\
\text { component } \\
\text { ) }\end{array}$ & $\begin{array}{l}\text { Educational } \\
\text { System in } \\
\text { Ukraine }\end{array}$ & $\begin{array}{l}\text { Nation } \\
\text { al and } \\
\text { historic } \\
\text { traditio } \\
\text { ns }\end{array}$ & Country & $\begin{array}{c}\text { Environment } \\
\text { al Policy of } \\
\text { Government. } \\
\text { Activities of } \\
\text { Political } \\
\text { Parties }\end{array}$ & $\begin{array}{c}\text { Developmen } \\
\mathrm{t} \text { of Ethnic } \\
\text { Cultural } \\
\text { Traditions in } \\
\text { Environment } \\
\text { al Protection, } \\
\text { Regional / } \\
\text { Oblast Level }\end{array}$ & $\begin{array}{c}\text { National } \\
\text { Environment } \\
\text { al Strategy. } \\
\text { River Basin } \\
\text { Administratio } \\
\text { ns }\end{array}$ \\
\hline $\begin{array}{c}\text { IV. } \\
\text { Landsca } \\
\text { pe } \\
\text { (junctio } \\
\mathrm{n} \\
\text { compon } \\
\text { ent) }\end{array}$ & $\begin{array}{l}\text { Forest- } \\
\text { steppe, } \\
\text { Steppe }\end{array}$ & $\begin{array}{l}\text { Territorial } \\
\text { Production } \\
\text { Complexes }\end{array}$ & $\begin{array}{l}\text { Budget, its } \\
\text { forming, } \\
\text { distributio } \\
\text { n and } \\
\text { spending }\end{array}$ & $\begin{array}{l}\text { Regional } \\
\text { Educational } \\
\text { Structure }\end{array}$ & $\begin{array}{c}\text { Ethnic- } \\
\text { cultura } \\
1 \text { and } \\
\text { nationa } \\
1 \\
\text { traditio } \\
\text { ns }\end{array}$ & $\begin{array}{c}\text { agglomerat } \\
\text { e } \\
\text { City/ } \\
\text { Town } \\
\text { (junction } \\
\text { component } \\
\text { ) }\end{array}$ & $\begin{array}{l}\text { Regional and } \\
\text { Municipal } \\
\text { Activity, } \\
\text { Activity of } \\
\text { Regional and } \\
\text { City/Town } \\
\text { Public } \\
\text { Organization } \\
\text { s }\end{array}$ & $\begin{array}{c}\text { Forming } \\
\text { Environment } \\
\text { al } \\
\text { Conscience } \\
\text { in } \\
\text { Professional } \\
\text { Groups }\end{array}$ & $\begin{array}{c}\text { Regional and } \\
\text { Municipal } \\
\text { Activity on } \\
\text { River Basin } \\
\text { Management }\end{array}$ \\
\hline $\begin{array}{c}\mathrm{V} . \\
\text { Bioceno } \\
\text { sis }\end{array}$ & $\begin{array}{c}\text { Junction } \\
\text { stages }\end{array}$ & $\begin{array}{l}\text { Enterprise } \\
\text { (junction } \\
\text { component } \\
\text { ) }\end{array}$ & $\begin{array}{l}\text { Budget on } \\
\text { Micro- } \\
\text { level } \\
\text { (junction } \\
\text { component } \\
\text { ) }\end{array}$ & $\begin{array}{c}\text { Higher } \\
\text { Education } \\
\text { Institution, } \\
\text { Secondary } \\
\text { Technical } \\
\text { Schools, } \\
\text { Secondary and }\end{array}$ & $\begin{array}{l}\text { Scienti } \\
\text { fic } \\
\text { School } \\
\text { s } \\
\text { (juncti } \\
\text { on }\end{array}$ & $\begin{array}{c}\text { Urban } \\
\text { socio- } \\
\text { ecosystems }\end{array}$ & $\begin{array}{l}\text { Activity on } \\
\text { the Level of } \\
\text { Enterprises } \\
\text { and } \\
\text { Institutions }\end{array}$ & $\begin{array}{c}\text { Forming } \\
\text { Environment } \\
\text { al } \\
\text { Conscience } \\
\text { in Enterprise } \\
\text { Personnel }\end{array}$ & $\begin{array}{c}\text { Water } \\
\text { Protection } \\
\text { Activities on } \\
\text { the Level of } \\
\text { Enterprises } \\
\text { and } \\
\text { Institutions, } \\
\text { and }\end{array}$ \\
\hline
\end{tabular}


Linnaeus ECO-TECH ' 10

Kalmar, Sweden, November 22-24, 2010

\begin{tabular}{|c|c|c|c|c|c|c|c|c|c|c|}
\hline & & & & & $\begin{array}{c}\text { Primary } \\
\text { Schools } \\
\text { (junction } \\
\text { component) }\end{array}$ & $\begin{array}{c}\text { compo } \\
\text { nent) }\end{array}$ & & & & $\begin{array}{l}\text { Administrativ } \\
\text { e Sections, } \\
\text { Local } \\
\text { Community }\end{array}$ \\
\hline $\begin{array}{c}\text { VI. } \\
\text { Populati } \\
\text { on }\end{array}$ & 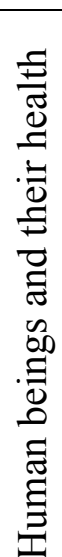 & $\begin{array}{c}\underset{\Xi}{\Xi} \cdot \frac{\vec{\Xi}}{\vec{\Xi}} \\
\text { Biodive } \\
\text { rsity }\end{array}$ & $\begin{array}{c}\text { (Human) } \\
\text { Population }\end{array}$ & Income & $\begin{array}{l}\text { Contingents of } \\
\text { teachers, } \\
\text { students and } \\
\text { pupils }\end{array}$ & $\begin{array}{c}\text { Person } \\
\text { alia }\end{array}$ & $\begin{array}{c}\text { Local } \\
\text { Communiti } \\
\text { es }\end{array}$ & $\begin{array}{l}\text { Individual } \\
\text { and Group } \\
\text { Activity of } \\
\text { Population }\end{array}$ & $\begin{array}{c}\text { Forming } \\
\text { Environment } \\
\text { al } \\
\text { Conscience } \\
\text { in } \\
\text { Professional } \\
\text { Groups (the } \\
\text { level of } \\
\text { Individual } \\
\text { and Family) }\end{array}$ & $\begin{array}{l}\text { Activities on } \\
\text { the Level of } \\
\text { Family and } \\
\text { Individual }\end{array}$ \\
\hline
\end{tabular}


It is well-known that floodplain is an important ecotone where processes of accumulation of surface runoff and groundwater flow, substance exchange between watercourse and its watershed, transformation and redistribution of chemical flow, i.e., all processes of selfpurification, are carried out.A specific feature of urban areas, from the point of view of forming surface runoff, is increase of in the quantity of point sources of pollution and decrease in quantity of diffuse sources. Their inputs escaping flooding areas go directly into watercourses or waterbodies. These make prerequisites for constructing eco-engineering facilities for collecting and treatment of polluted surface runoff and groundwater flow.

\section{COMPOSITIONS OF ECO-ENGINEERING FACILITIES IN FLOODPLAINS}

General structure of these facilities can be the following. It is suggested that surface runoff collection will be carried out from unit watersheds or their built-up areas. Surface runoff will be directed in floodplain where these waters at first get to floodplain water bodies like ox-bow lakes, bayou lakes etc. or their man-made counterparts. A key diagram of treatment system will include larger accumulation pond (a counterpart of ox-bow lakes) which capacity will be defined by the volume of calculated maximally expected rain or snow store. Its function is to accumulation of runoff waters and sedimentation of solids. This pond will be connected via filter ditches with the system of lesser shallow water bodies having inputs into river. Their function is water treatment and conditioning (see Figure 1).

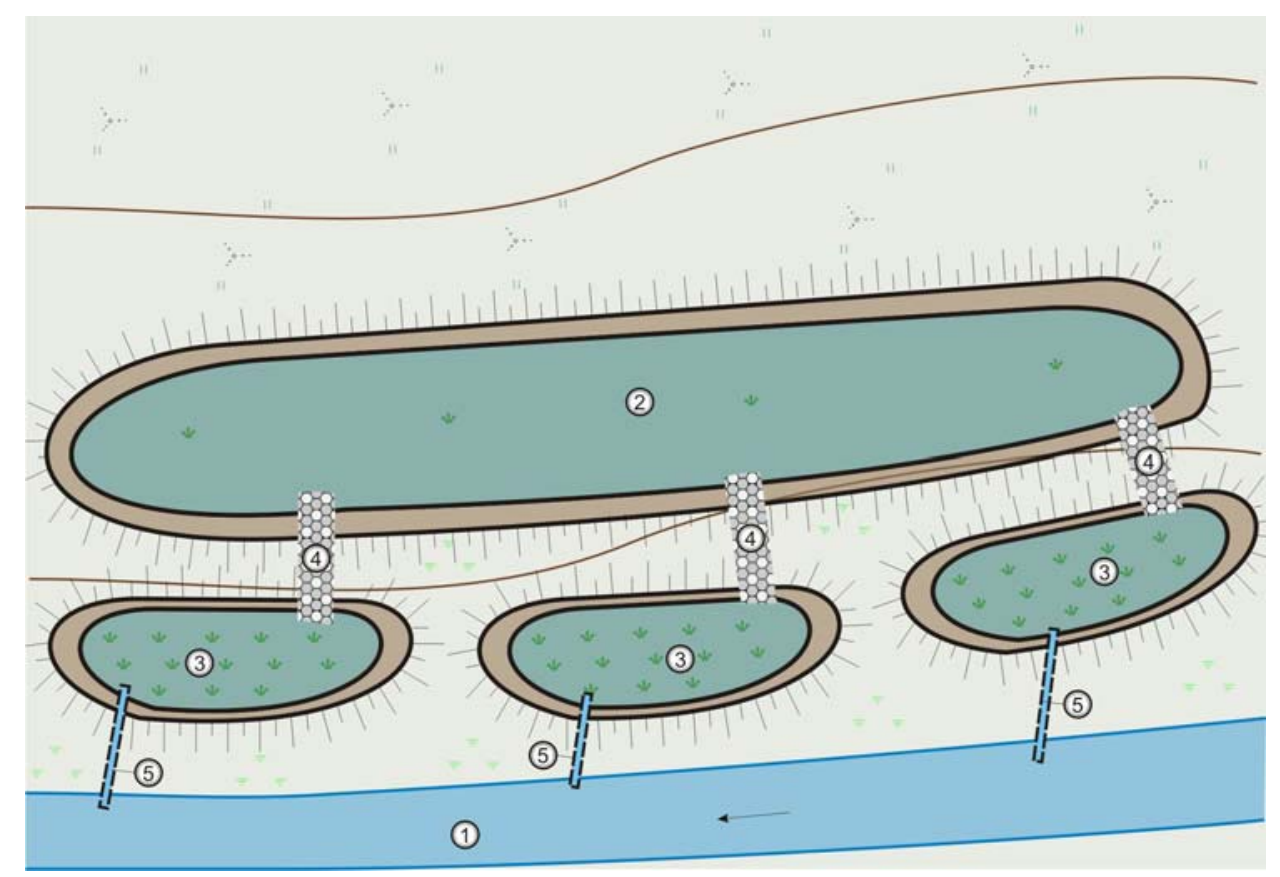

Figure 1 A layout of eco-engineering treatment facilities in floodplain

1-river; 2- collecting (accumulating) pond; 3-constructed wetlands; 4- permeable gravel trenches (channels); 5- spillway pipes. 
In the case of pond overflow under conditions of catastrophic rain or snow melt after snowy winter the overflow will input to floodplain or flooding territory on the strips with tree and shrub vegetation.During drought seasons these ponds will slowly draw-off contributing to watering green stands in riparian water protective zones and re-watering river during low water period.For river banks with steep slopes in riparian water protective zone it is suggested to create green stands, also used as a place for recreation, whose sufficient feature will be collecting ponds for treatment of surface runoff from housing areas located above them. The arrangement of the mentioned ponds depends on local conditions. They would be: (1) ponds having outlets into river; (2) ponds situated in cascades on river terraces.In the case of widely developed ravine and gully network it will be exposed to land-planning and engineering modifications. Ravines and gullies are broken on sections creating cascades. Permeable barriers will be built of local natural materials like stone, wood, clay with the use of young hygrophilous tree and shrub plants like species of willows, poplars, alders, aspens etc. Mouths of ravines (debris cone) are transformed into natural or artificial stands of rooted higher aquatic vegetation. Riparian zone with steep slopes should have continuous tree and shrub stands (see Figure 2).

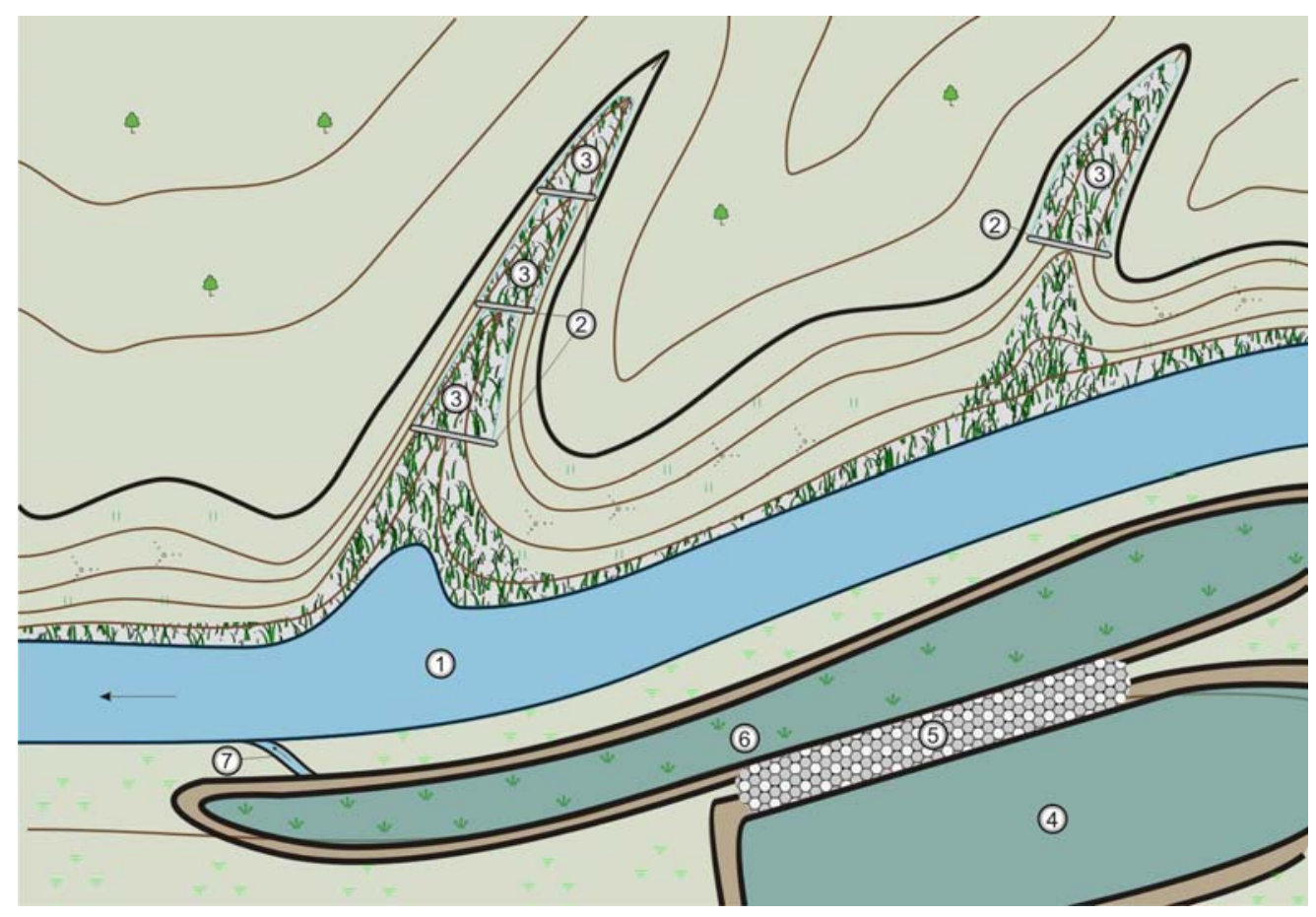

Figure 2 A layout of eco-engineering treatment facilities with the use of ravine and gully network.

1- river; 2- permeable barriers in ravines; 3- cascaded sections in ravines; 4- collecting (accumulating) pond; 5-permeable gravel dam; 6- constructed wetland; 7- outlet channel. 
It is suggested that the accumulating ponds will be used for collecting runoff waters, runoff load levelling, sedimentation and pollutant transformation. Waterbodies following the accumulating ponds will be constructed wetlands of various kinds (so called free water surfaces, FWS).

\section{LAND-PLANNING AND ARCHITECTURAL SOLUTIONS FOR FLOODING TERRITORIES}

Eco-engineering treatment facilities can also be a recreation site, a part of urban recreation zone, placed astride rivers. As a rule, the most expressive views and contrast combination of various functions are connected with water spaces. The state of bank areas possessing great natural potentials can tell much about the level of urban environment humanization, and its compliance with needs of population.

One of the most pressing problems in using bank areas is providing population access to water space in the city. River banks in urban areas usually have continuous development. Optimum in this situation could be green eco-corridors along the river in the form of park at the expense of demolition of houses of little value and clearance of industrial facilities. Additionally changes in the content of land use require reorganisations in transport infrastructure and forming areas with mainly pedestrian traffic. In the case of placing water front outline close to city mains it is necessary to create an artificial relief for visual and noise-protective delimitations pedestrian and traffic spaces.

Green corridors along river through breaks in urban development with the aid of horns (branches) would connect the recreational zone of the river with the system of city parks, public gardens and boulevards forming a well-balanced urban environment. This corridor creating healthy microclimate is the optimal place for recreation of citizens therefore it is reasonable to transform it into a popular park including wide promenades and refinement of landscape views which provide river banks the feature of environmental stability under conditions of their heavy use. Minimising the role of such traditional park components like alleys and squares, popular park increases significance of all kinds of open spaces where human can walk afoot, ride a bicycle or on horseback or go boating (see Figure 3). 


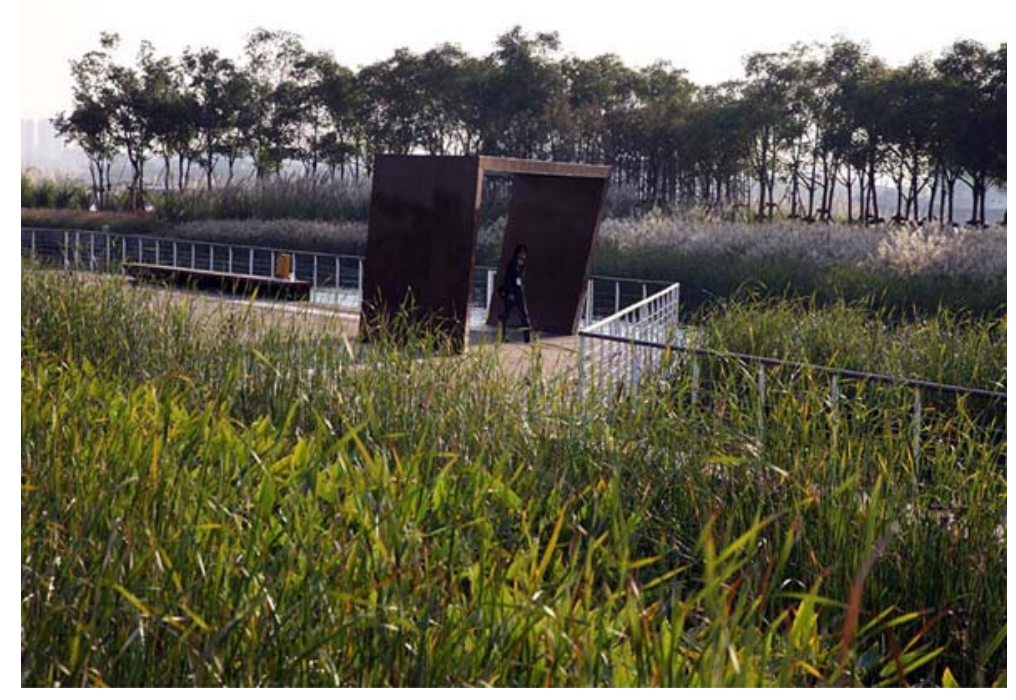

Figure 3 An example of successful application of an integrated solution concerning floodplain wetland in modern urban agglomerate in Shanghai Houtan Park (Shanghai, China) [5].

Planning of such a park would allow its visitors to come nearer to river water surface to maximal extent and to lead them away from the zones of accumulating lagoons containing polluted waters. The system of eco-engineering treatment facilities can be the object of landscape design. It can be built in the form of ponds or their cascades with series of grounds for silent rest. Distances for walk routes can be lengthened at the expense of paths with wooden cover on piles that could create the effect of walking on the surface of vegetation, e.g., shrubs, grasses etc. As far as the territory of park along the river characterised by extended shape it is necessary to create a system of irregular ("pulsatory") polyfunctional spaces, figurative and dynamic, which could provide possibilities for recreation.

When organising park space the taken approach to landscape design is of great significance. The appropriate approach can contribute much in reshaping the territory intended for landscaping to the park with unique, new and inimitable appearance.

\section{ECOLOGICAL ROLE OF RIPARIAN PROTECTIVE ZONE IN FUNCTIONING CITIES AND TOWNS}

The role of ecotones, particularly riparian and coastal areas, is well-known and does not discuss in this article. We do emphasise that in the "city" system the role of floodplain and coastal areas is unique since they are specific places where the flow of pollutants including some products of human and urban activities from various point and diffuse sources can be effectively intercepted and transformed under control but without human direct participance, i.e., these are places where pollutants are processed by reducers - soil and rhizosphere 
bacteria and, especially, fungus. In other words, urban diffuse runoff can be intercepted and transformed by secure "green" filter.

\section{CONCLUSIONS}

The proposed facilities are not full-scale and comprehensive solution for preventing river pollution but they, in the case of their realisation, could permit to sufficiently decrease polluting loading without additional sources of energy. Processes of run-off treatment will carry out at the expense of intensifications of trophic connections in ecosystems and ecotones. However all these changes will be possible only after revisions in land planning and architectural concepts of urban development.

The mentioned above technical solutions on the base of sustainable land planning and use of ecotechnologies do not cancel use of protective hydraulic structures and application of protective measures for housing areas and transport infrastructure from floods. These protective structures, like river dikes, floodwalls etc., may be moved away from river bank and situated between run-off treatment facilities and housing areas.

It is assumed that all said above could be a decisive step towards changes in existing approaches and prevalent principles in land planning, land use, urban development and understanding the role of rivers in contemporary urban and industrial areas, more ecological compatibility taking into account more holistic landscape vision with a glance to greater sustainability.

\section{REFERENCES}

[1] National Report about the Environmental State of Ukraine in 2007. /The Ministry of the Environment, Ukraine. - Kyiv, 2008. (in Ukrainian and English)

[2] Kharkiv. General City Planning Scheme. Vol. 2. - Kyiv, 2003, 185 p. (Ukrainian State R\&D Institute of City Planning, DIPROMISTO)

[3] Report, 2009. Results of analytic control of surface waters in Kharkivs'ka Oblast. /State Administration on the Environment and Natural Resources in Kharkivs'ka Oblast. Kharkiv, 59 p.

[4] Shatrovskiy, A.G. \& Spirin, A.I., 2002. A Natural Hyerarchy of Urbanistic Systems. Kommunal'noe khozyastvo gorodov. 36, 173-177.

[5] Shanghai Houtan Park / Shanghai, China. -Architects: Turenscape, China and Peking University, Graduate School of Landscape Architecture, http://www.gardener.ru/?id=1983 